ISSN: 2332-2748

\title{
Photostimulation in the Process of the Cryopreservation of Sperm Cells
}

Editorial

\author{
Ali Doğan ÖMÜR*
}

Associate Professor, Atatürk University, Turkey.

It is an important issue that genetic resources are kept and transferred to the next years. The process of cryopreservation of semen which has a wide usage area such as reproduction biotechnology, species protection and clinical applications is of great importance in this sense. It will be ensured that the semen is frozen in a way to ensure adequate fertilization, artificial in semination applications will be more practical and economical and more accurate and reliable pedigree records will be kept. In addition, the use of animals with high genetic capacity in large populations will become possible.

Developments in the light of recentre search have been directed towards increasing fertility capabilities, after thawing sperm cells particularly by photostimulation effect in different spectrum areas [7].

Because of the irline arity, single-wave length, stable radiation and high power, lasers are found in many areas of our lives. Thanks to its narrow focusing advantages, laser sources are increasingly recognized in various industries $[4,5,8]$.

Recently, it has been shown that the in vitro conditions of boar sperm cells increase in resistance and capacitation under intense irradiation of red LED (Light Emitting Diode) lights and fertility ability is increased in vivo as well [7]. Consistent results have also been obtained in species such as humans, dogs, bulls, rams and rabbits using devices and systems such as low energy lasers and visible light lamps at wave lengths ranging from $400 \mathrm{~nm}$ to $800 \mathrm{~nm}$ [1]. It can be said that these results have two main reflections. The first is the idea of increasing the reproductive activity of domestic animals with simple structured light emitting devices, in which sense the introduction of such devices has started at least in the field of pig breeding (MaxiPig ${ }^{\mathcal{O}}$; Iul S.L.; Barcelona, Spain). The second is to optimize the mechanism of stimulation of sperm cells by specific light rays. This is important as it can provide invaluable information on the function of sperm cells and at the same time optimum strategies can be developed to improve the in vivo reproductive performance of domestic animals. Further more, in the light of the studies, photostimulation applications related to the evaluated wave lengths do not change or decrease the levels of free oxygen radicals $[2,3,6]$. This poses a positive situation against the harmful effects of free oxygen radicals formed during the cryopreservation process.

\section{References}

[1]. Abdel-Salam Z, Harith MA. Laser researches on livestock semen andoocytes: a brief review. J AdvRes. 2015 May; 6(3): 311-7. PMID: 26257928.

[2]. Antognazza MR, Abdel Aziz I, Lodola F. Use of Exogenous and Endogenous Photomediators as Efficient ROS Modulation Tools: Results and Perspectives for Therapeutic Purposes. Oxidative medicine and cellular longevity. 2019.

[3]. Huang YY, Nagata K, Tedford CE, McCarthy T, Hamblin MR. Low-level laser therapy (LLLT) reduces oxidative stress in primary cortical neurons in vitro. J Biophotonics. 2013; 6(10): 829-38. PMID: 23281261.

[4]. Kim CH, Ahn DC. Coaxial monitoring of keyhole during Yb: YAG laser welding. Optics \& Laser Technology. 2012 Sep 1; 44(6): 1874-80.

[5]. Cui L, Li XY, He DY, Chen L, Gong SL. Study on microtexture of laser welded 5A90 aluminium-lithium alloys using electron backscattered diffraction. Science and Technology of Welding and Joining. 2013 Apr 1; 18(3): 204-9.

[6]. Pezo F, Zambrano F, Uribe P, Ramírez-Reveco A, Romero F, Sanchéz R. LED-based red light photostimulation improves short-term response of cooled boar semen exposed to thermal stress at $37^{\circ} \mathrm{C}$. Andrologia. $2019 \mathrm{Jun}$; 51(5): e13237. PMID: 30656707.

[7]. Yeste M, Codony F, Estrada E, Lleonart M, Baslasch S, Peña A, et al. Specific LED-based red light photo-stimulation procedures improve overall sperm function and reproductive performance of boar ejaculates. SciRep Open Access publication. 2016; 6: 22569. PMID: 26931070.

[8]. You DY, Gao XD, Katayama S. Review of laser welding monitoring. Science and technology of welding and joining. 2014 Apr 1; 19(3): 181-201.

Special Issue on
"Animal Reproduction Science"
Theme Edited by:
Ali Doğan ÖMÜR,
Assistant Professor, Atatürk University,
Erzurum.
E-mail: alidogan@atauni.edu.tr

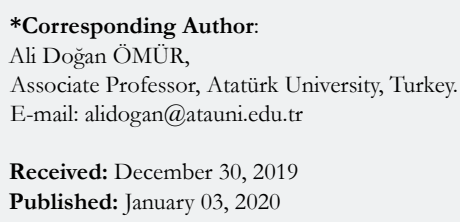

Copyright: Ali Doğan ÖMÜR ${ }^{\circ}$ 2020. This is an open-access article distributed under the terms of the Creative Commons Attribution License, which permits unrestricted use, distribution and reproduction in any medium, provided the original author and source are credited. 